\title{
The Status of Laying Traits in Indigenous Chicken of Bangladesh: A Review
}

\author{
M. Shahjahan
}

10.18805/ag.R-185

\begin{abstract}
This paper covers the review of diversified performance of laying traits of Bangladeshi indigenous chicken in both in situ and ex situ including few global studies. Indigenous chicken constitutes about $80 \%$ of the total chicken population in Bangladesh and their different genotypes distribute throughout the country having distinct morphological and productive characteristics. The common native genotypes (usually non-descript or deshi) provide $35-45$ eggs annually with $83-96 \%$ egg fertility and $75-88 \%$ hatchability in free range while better performance is observed in extensive system. Although Naked Neck and Hilly chicken genotypes perform superior but they are not available like common deshi. The genetic improvement of laying traits is a challenging work for the village chicken in Bangladesh, however, the planned breeding strategies along with improvement management system could enhance the activity. The results presented in this review would be a guideline for selection of indigenous chicken to improve further its productivity and conservation aspect. Thus, a conceptual breeding strategy is proposed here for the improvement of laying traits in village chicken insitu as uncontrolled mating occurs there compared to ex-situ condition.
\end{abstract}

Key words: Breeding strategies, Community breeding, Egg, Fertility, Hatchability, Native, Production.

Bangladesh is an agro-based country where its livestock contributes $2.79 \%$ of GDP and $17.15 \%$ of agricultural share (IUCN, 2011). Livestock rearing is a vital part of rural small or medium scale farming where the most popular poultry species is indigenous or native chicken followed by duck and pigeon under traditional or backyard (in situ) management system. About 130 million native chickens are distributed throughout the country (Sørensen, 2010) occupying $80 \%$ of the total chicken populations (DLS, 1998) and contribute a large part of meat (78\%) and egg (75\%) production locally (Bhuiyan et al., 2005).

Bangladeshi native chicken are mainly classified into common native birds of non-idiosyncratic type or Nondescript (Deshi or ND), Naked Neck (NN), Hilly (H), Aseel, Yasine, Frizzle plumage and Native dwarf genotypes where Deshi chickens constitute about $90 \%$ of the total native chicken population and others are endangered or critically endangered or extinct (Bhuiyan et al., 2005; Das et al., 2008). The indigenous chicken genotypes of Bangladesh are considered as one breed for small genetic distances among them (Okada et al., 1987), but their performance and morphological characters are distinct from each other. The village chicken is characterized by $35-45$ eggs annually (Bulbul, 1983; Ahmed and Islam, 1985; Sazzad et al., 1990; Huque and Huque, 1990; Amin and Bhuiyan, 1995; Ershad, 2005). Among the available indigenous chicken genotypes in Bangladesh, Naked Neck is still considered superior for egg production and quality (Barua et al., 1992; Islam and Nishibori, 2009; Faruque et al., 2013). Native chickens are a huge treasure of variable genotypes (Yeasmin and Howlider, 1998) and the reservoirs of various adaptive traits controlling useful genes (Horst, 1989).

As huge studies are performed with village chicken so far, a summarized review including all the vital laying traits
Bangladesh Livestock Research Institute, Regional Station, Baghabari, Shahjadpur, Sirajganj, Bangladesh.

Corresponding Author: M. Shahjahan, Bangladesh Livestock Research Institute, Regional Station, Baghabari, Shahjadpur, Sirajganj, Bangladesh. Email: sajubau@gmail.com

How to cite this article: Shahjahan, M. (2021). The Status of Laying Traits in Indigenous Chicken of Bangladesh: A Review. Agricultural Reviews. 42(3): 247-256. DOI: 10.18805/ag.R-185.

Submitted: 21-12-2020 Accepted: 31-03-2021 Online: 22-04-2021

is required to screen and further decision making on the development of those native chicken genetic resources. Therefore, the laying performance traits of indigenous chicken located in various geographical locations or agro-ecological zones in both free range and intensive systems are described here. In addition, the effects of possessing various plumage colours, genotypes and age on laying traits of Bangladeshi indigenous chicken are also shown along with research based justifications of other countries.

\section{Effect of geographical location on laying traits of indigenous chicken}

The laying performance of indigenous chicken studied in different districts or agro ecological zones of Bangladesh has been depicted (Table 1). Age at first laying was observed earlier in the hen of Rajshahi district (Dutta et al., 2013). Clutch length of chicken was found lower in Sherpur district (Shahjahan et al., 2011) than south part of country at Noakhali after early weaning of chicks from hens (Sarkar and Bell, 2006). Sarkar and Golam (2009) identified an average 14.60 eggs per clutch and 3.10 clutches per year in local chicken of different districts of Chittagong division but annual clutch number was found higher in Mymensingh 
district (Shahjahan et al., 2011) followed by Saver region of Dhaka (Sazzad, 1993). The average annual egg production (68 eggs), egg weight $(42.71 \mathrm{~g})$ and hatchability $(87.11 \%)$ were recorded highest in northern parts (Ahmed et al., 2012) while fertility (93.83\%) was in western parts (Dutta et al., 2013) of Bangladesh. These variations in performance could be the results of individual genetic background, availability of feed or nutrients and care of birds.

In Ethiopia, Tadelle et al. (2003) studied egg production of native chicken in five ecotypes where average egg production per clutch (17.70 eggs) was found higher than the findings of Bangladesh but annual clutch number (2.60) was lower. Another experiment in Ethiopia by Mogesse (2007) depicted that age at first laying in the local chicken of Debre Elias (143.67 days) was lowest and Melo-
Hamusite (168.33 days) ecotypes recorded highest out of seven ecotypes which was in concurrence to our country's findings.

\section{Effect of plumage colours (gene pooled) on performance of local chicken}

Various plumage colours were observed in the indigenous chicken while few of those appeared predominantly. Thus, gene pooled predominant plumage colours remain as a subject of interest for a basic traditional tool of selection, although studies are very limited in this aspect. The laying traits (Table 2) of Bangladeshi native chicken identified by Shahjahan et al. (2011) were based on six predominant plumage colours (Fig 1) while lower production was reported previously by Islam et al. (2007).

Table 1: Performance of indigenous in different region of Bangladesh.

\begin{tabular}{|c|c|c|c|}
\hline Trait & Value & District or location & Reference \\
\hline \multirow[t]{4}{*}{ Age at first laying (d) } & 175 & Jessore & Ershad (2005) \\
\hline & 151.67 & Rajshahi & Dutta et al. (2013) \\
\hline & 192.60 & Sherpur & Shahjahan et al. (2011) \\
\hline & 216 & Mymensingh & Shahjahan et al. (2011) \\
\hline \multirow[t]{3}{*}{ Clutch length (d) } & 21 & Noakhali & Sarkar and Bell (2006) \\
\hline & 16.83 & Sherpur & Shahjahan et al. (2011) \\
\hline & 19.68 & Mymensingh & Shahjahan et al. (2011) \\
\hline \multirow[t]{3}{*}{ Egg per clutch } & 14.60 & Feni, Noakhali and Luxmipur & Sarkar and Golam (2009) \\
\hline & 15.23 & Sherpur & Shahjahan et al. (2011) \\
\hline & 16.32 & Mymensingh & Shahjahan et al. (2011) \\
\hline \multirow[t]{4}{*}{ Clutch per year } & 3.50 & Dhaka & Sazzad (1993) \\
\hline & 3.10 & Feni, Noakhali and Luxmipur & Sarkar and Golam (2009) \\
\hline & 3.17 & Sherpur & Shahjahan et al. (2011) \\
\hline & 3.63 & Mymensingh & Shahjahan et al. (2011) \\
\hline \multirow[t]{6}{*}{ Annual egg production } & 42 & Dhaka & Sazzad (1993) \\
\hline & 44 & Jessore & Ershad (2005) \\
\hline & $40-54$ & Noakhali & Sarkar and Bell (2006) \\
\hline & 45.50 & Feni, Noakhali and Luxmipur & Sarkar and Golam (2009) \\
\hline & 68.27 & Gazipur and Mymensingh & Ahmed et al. (2012) \\
\hline & 40.42 & Rajshahi & Dutta et al. (2013) \\
\hline \multirow[t]{2}{*}{ Egg weight (g) } & 36.27 & Jessore & Ershad (2005) \\
\hline & 42.71 & Gazipur and Mymensingh & Ahmed et al. (2012) \\
\hline Fertility (\%) & 93.83 & Rajshahi & Dutta et al. (2013) \\
\hline \multirow[t]{4}{*}{ Hatchability (\%) } & 66.67 & Noakhali & Sarkar and Bell (2006) \\
\hline & 82.90 & Feni, Noakhali and Luxmipur & Sarkar and Golam (2009) \\
\hline & 87.11 & Gazipur and Mymensingh & Ahmed et al. (2012) \\
\hline & 85.67 & Rajshahi & Dutta et al. (2013) \\
\hline
\end{tabular}

Table 2: Performance of laying traits in indigenous chicken based on predominant plumage colours.

\begin{tabular}{|c|c|c|c|c|c|c|c|}
\hline \multirow[b]{2}{*}{ Trait } & \multicolumn{6}{|c|}{ Predominant plumage colour } & \multirow[b]{2}{*}{ Reference } \\
\hline & Black & Red & $\begin{array}{c}\text { Blackish } \\
\text { red }\end{array}$ & $\begin{array}{c}\text { Reddish } \\
\text { black }\end{array}$ & $\begin{array}{l}\text { Whitish } \\
\text { black }\end{array}$ & $\begin{array}{c}\text { Blackish } \\
\text { white }\end{array}$ & \\
\hline \multirow[t]{2}{*}{ Egg per clutch } & 13.31 & - & 13.43 & - & - & 11.71 & Islam et al. (2007) \\
\hline & 16.00 & 16.18 & 14.77 & 16.06 & 16.50 & 13.14 & Shahjahan et al. (2011) \\
\hline Clutch per year & 3.25 & 3.32 & 3.03 & 3.41 & 3.00 & 3.00 & Shahjahan et al. (2011) \\
\hline Annual egg production & 51.63 & 53.41 & 45.49 & 55.41 & 49.00 & 39.43 & \\
\hline
\end{tabular}




\section{Effect of genotype and age on the performance of laying traits in native chicken}

\section{Reproductive efficiency and egg production}

The reproductive efficiency and egg production performance of indigenous chicken genotypes (Fig 2) of Bangladesh are presented in Table 3. Early sexual maturity is an important trait for egg production in hen which was revealed by laying of first egg. The findings of Faruque et al. (2007), (2010), (2013) and (2015) were investigated lower days for laying first egg in ND (155-157 days), NN (152.70-156.10 days) and $H$ (152.10-159.10 days) chicken genotypes in ex situ which could be the reasons of better management and systemic selection overtimes in case rearing which was supported the findings of Dutta et al. (2013) at in-situ condition with better management too. But delayed sexual maturity was observed by Shahjahan et al. (2011) for laying first egg in ND/FF (203 days) and NN (202 days) genotypes were in agreement with the results of Barua (1992) for ND hen and Jahan et al. (2017) for NN chicken. Moderate sexual maturity in common deshi hen (ND) was identified within 175 days (Huque, 2001; Jahan, 2013) which was supported by the findings of Yeasmin et al. (2003). Similar observation was also reported in NN (234 days) and Aseel (240-300 days) genotypes by Huque (2001). Ahmed et al. (2012) found 14.93 and 15.18 days of clutch length in ND and NN hens, respectively. Another type of ND chicken named Cap Headed $(\mathrm{CH})$ showed the average age at first laying in 182 days, 16.43 days length per clutch, 15.43 eggs per clutch, 3.50 clutch per year and 46 eggs annually (Shahjahan et al., 2011) which was also supported by Jahan (2013).

The study of Shahjahan et al. (2010) revealed height egg production per clutch in village chicken at 37-66 month of age (17.33 egg) while Islam et al. (2007) showed comparatively lower at 25 months or above age (14 eggs per clutch) in village chicken of Bangladesh. The annual egg production of native ND hen was studied 35-40 (Sazzad et al., 1990), 35-45 (Bulbul, 1983; Amin and Bhuiyan, 1995)
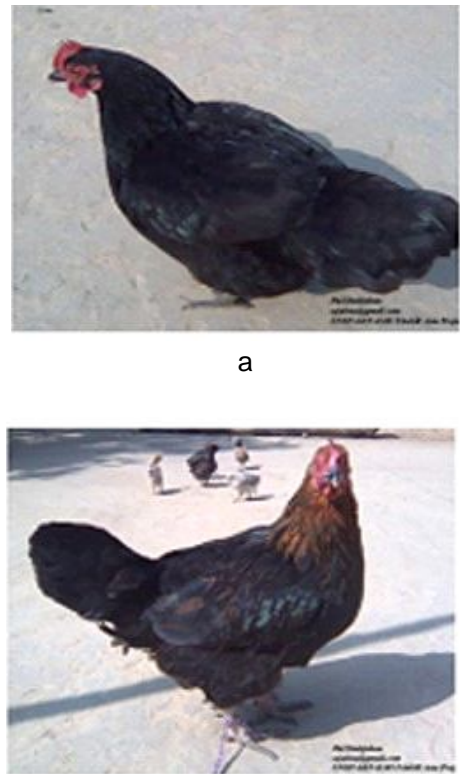

d
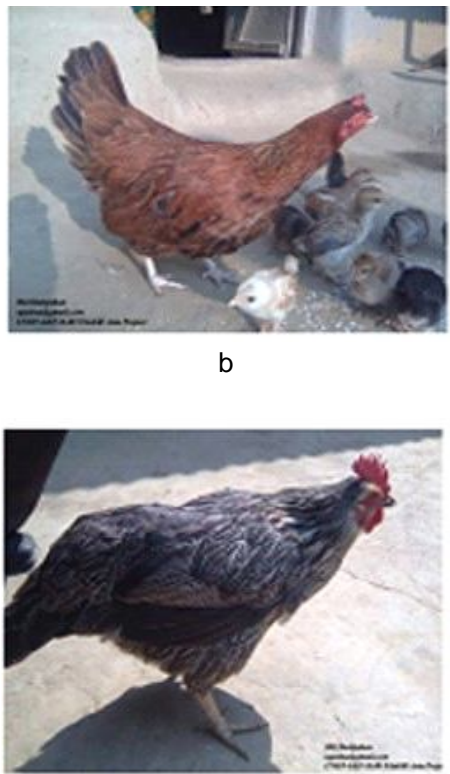

e

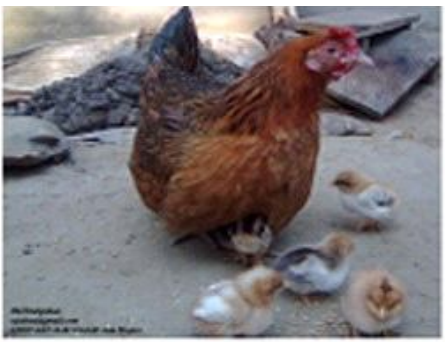

C

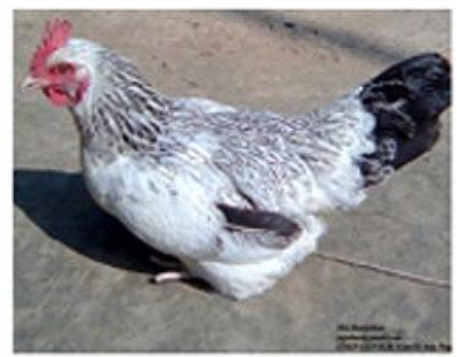

f

Fig 1: Six predominant (gene pooled) plumage colours in indigenous chicken; (a) Black, (b) Red, (c) Blackish red, (d) Reddish black, (e) Whitish black and (f) Blackish white. (Source: Shahjahan et al., 2011).

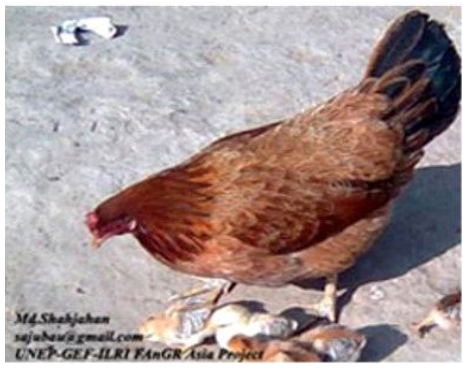

a

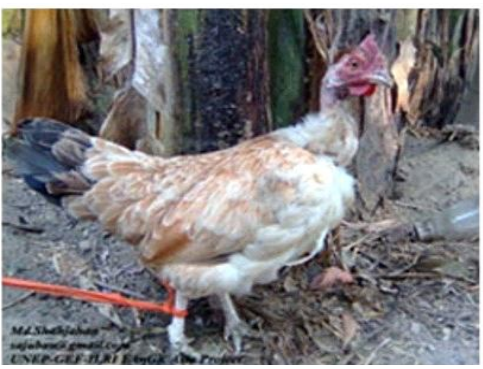

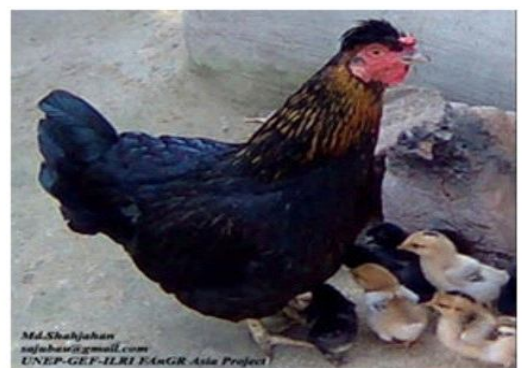

C

Fig 2: Available indigenous chicken genotypes of Bangladesh: (a) Non-descript/Full Feathered/Common Deshi (ND/FF), (b) Naked Neck (NN) and (c) Crested/Crown/Cap Headed (CH) (Source: Shahjahan et al., 2011). 
and 40-45 (Ahmed and Islam, 1985; Huque and Huque, 1990; Ershad, 2005) which was supported by the findings of Sarkar and Bell (2006) and Sarkar and Golam (2009). Huque (2001) reported annual egg production in ND (45-50 eggs) and Aseel (33 eggs) genotypes of Bangladesh. The observation of Yoshimura et al. (1997) pertaining to annual egg production (50-55 eggs) of NN hen did not match with the results of Ahmed et al. (2012) who was found higher annual egg production in NN (71 eggs) and ND (67 eggs) genotypes. Paul and Huque (1996) also confirmed better annually egg production in NN (99 eggs) and H (91 eggs) genotypes but similar productive trait was not found in Yasine (58 eggs) and Assel (34 eggs) in ex situ. More than double laying performance (up to 99 eggs and 5.53 clutches per year) could be possible in free range by little changes in management practices like early weaning and creep feeding (Sarkar and Bell, 2006) which was agreed with Khan (1983) in intensive system.

In India, Sunder et al. (2005) and Sharma (2004) observed delayed age at first laying on 186 and 203 days in native hen, respectively, which were in agreement with the data of Bangladeshi native chicken. But early maturity age was comparatively lower to the Indian improved backyard Vanaraja (152 days), Gramapriya (145 days) breeds except in Aseel (184 days) chicken (Sree et al., 2017). Benabdeljelil et al. (2001) supported the previous reports for age at first laying in the native Beldi chicken genotype with an average of 3 clutches per year, 13.5 eggs per clutch and 78 eggs annually in Morocco. The experiment of Farooq et al. (2003) confirmed maximum 14 days for clutch length in different seasonal variation of Pakistani deshi hen. Mwalusanya et al., (2001) studied the average performance of Tanzanian native chicken on eggs per clutch (11.80), clutches per year (2.68) and annual egg production (31.60) which were lower than our country's findings mentioned before but similar results were observed in the traits of clutch length per year, egg per clutch and annual egg production in Ethiopian Shayi (4, 13 and 52 ), Selamber (4, 15 and 60) and Bechi (4 clutch per year, 14 eggs per clutch and 56 eggs annually) chicken, respectively (Abegaz and Gemechu, 2016). Petrus (2011)

Table 3: Reproductive efficiency and egg production performance of native chicken genotypes in Bangladesh.

\begin{tabular}{|c|c|c|c|c|c|}
\hline \multirow[b]{2}{*}{ Trait } & \multicolumn{3}{|c|}{ Genotype } & \multirow[b]{2}{*}{ Assel } & \multirow[b]{2}{*}{ Reference } \\
\hline & $\begin{array}{c}\text { Deshi } \\
\text { (ND/FF) }\end{array}$ & $\begin{array}{c}\text { Naked Neck } \\
(\mathrm{NN})\end{array}$ & $\begin{array}{r}\text { Hilly } \\
(\mathrm{H})\end{array}$ & & \\
\hline \multirow[t]{7}{*}{ Age at sexual maturity (d) } & 225 & & & & Barua (1992) \\
\hline & 175 & 234 & & $240-300$ & Huque (2001), Ershad (2005) \\
\hline & 169 & & & & Yeasmin et al. (2003) \\
\hline & $155-157$ & $\begin{array}{l}152.70- \\
156.10\end{array}$ & $\begin{array}{l}152.10- \\
159.10\end{array}$ & & $\begin{array}{l}\text { Faruque et al. (2007), (2010), } \\
\text { (2013) and (2015) }\end{array}$ \\
\hline & 203 & 202 & & & Shahjahan et al. (2011) \\
\hline & $133-168$ & & & & Dutta et al. (2013) \\
\hline & 175 & 185 & & & Jahan et al. (2017) \\
\hline \multirow[t]{2}{*}{ Clutch length (d) } & 18.07 & 20.50 & & & Shahjahan et al. (2011) \\
\hline & 14.93 & 15.18 & & & Ahmed et al. (2012) \\
\hline \multirow[t]{4}{*}{ Egg per clutch } & $12-18$ & & & & Sarkar and Bell (2006), Sarkar and Golam (2009) \\
\hline & 15.64 & 18.88 & & & Shahjahan et al. (2011) \\
\hline & 13.47 & 19 & & & Shahjahan and Bhuiyan (2016) \\
\hline & 11.04 & 12.03 & & & Jahan et al. (2017) \\
\hline \multirow[t]{3}{*}{ Clutch per year } & $3-4$ & & & & Sarkar and Golam (2009) \\
\hline & 3.38 & 3.63 & & & Shahjahan et al. (2011) \\
\hline & 2.75 & 3.50 & & & Shahjahan and Bhuiyan (2016) \\
\hline \multirow[t]{9}{*}{ Annual egg production } & $35-45$ & & & $24-48$ & $\begin{array}{l}\text { Bulbul (1983), Ahmed and Islam (1985), } \\
\text { Huque and Huque (1990), Sazzad et al. (1990), } \\
\text { Amin and Bhuiyan (1995), Ershad (2005), } \\
\text { Sarker et al., (2011), Huque (2013) }\end{array}$ \\
\hline & 135 & 99 & 91 & 34 & Khan (1983), Paul and Huque (1996) \\
\hline & & $50-55$ & & & Yoshimura et al. (1997) \\
\hline & $45-50$ & & & 33 & Huque (2001) \\
\hline & $40-54$ & & & & Sarkar and Bell (2006) \\
\hline & $36-68$ & & & & Sarkar and Golam (2009) \\
\hline & 50 & 53 & & & Shahjahan et al. (2011) \\
\hline & 67 & 71 & & & Ahmed et al. (2012) \\
\hline & 84 & 74 & 76 & & Faruque et al. (2015) \\
\hline
\end{tabular}


pointed out genotype and age pool annual egg production of indigenous chicken in Senegal and Kashmir (50-60 eggs) and Morocco (60-80 eggs) which were agreed with most of our country's findings but was not similar with Jordan (1830 eggs), Somalia (100-144 eggs) and Namibia (100-150 eggs) and other Indian improved backyard chicken breeds viz. Vanaraja (160 eggs), Gramapriya (178 eggs) and Aseel chicken (62 eggs). However, due to the variation of two managements in the indigenous chicken rearing at Egyptian rural areas, it was found that there was an average of 183 and 87 eggs annually in full adoption package group and non-adoption package groups, respectively (Hamouda et al., 2018) which were partially agreed with our findings.

\section{Fertility and hatchability}

In free range, it was observed that egg fertility and hatchability (Table 4) waslower (Hoque et al., 1975; Barua, 1992; Sarkar and Golam, 2009) in common deshi (ND) chicken than intensive system (Islam et al., 2001; Khatun et al., 2005) except Dutta et al. (2013) who stated maximum $96 \%$ fertility and $88 \%$ hatchability and also Shahjahan et al. (2011) reported in ND (88.74\%), NN (93.50\%) and $\mathrm{CH}$ $(89.20 \%)$ types of chicken while highest records were identified at $16-20$ months of age group $(90.64 \%)$ in the rural area of Bangladesh. Faruque et al. (2010) and (2013) studied egg fertility and hatchability on ND, NN and $\mathrm{H}$ genotypes in intensive system which was not in agreement with Huque and Salahuddin (2001) who pointed out much lower egg fertility and hatchability in NN, H, Assel and Yasine chicken genotypes of Bangladesh in same rearing system. In extensive system, average egg hatchability performance (85-87\%) of native chicken could be influenced by incubation system (Bhuiyan et al., 2005), availability of feed and routine physical exercise (Das et al., 2008), egg fertility and hygiene, seasonal temperature and humidity, size and number of incubated eggs and body surface of hen. In addition, eggs fertility of hen mainly depends on the availability of breeding cock, maturity of chicken with functional gonads, nutritional and hormonal balance, mating preference, timing and sperm quality. However, the best HDEP $(51.40 \%)$ and HHEP (49.70\%) production were observed in ND chicken genotypes compared to others (Faruque et al., 2015).

Hossary and Galal (1994) studied on fertility (87-96\%) and hatchability (77-89\%) for Egyptian Fayoumi native hen at one year of age in intensive care which was similar to the results of Bangladeshi village chicken and these results were supported by the findings of Abegaz and Gemechu (2016) for hatchability percentage in Ethiopian Shayi (80\%), Selamber (82\%) and Bechi (78\%) chicken in confined areas. In addition, such hatchability percentage was supported by Khank (2004) of Vietnam and Mwalusanya et al. (2001) of Tanzania and showed slightly lower in Beldi chicken (71\%) of Morocco (Benabdeljelil et al., 2001). Mogesse (2007) reported $85-100 \%$ fertility in Ethiopian native chicken. In Pakistan, Parveen et al. (2013) stated season-based hatchability of native chicken in winter $(65.43 \%)$, summer $(49.70 \%)$ and rainy $(44.45 \%)$ seasons which were much lower than previous studies.

\section{Egg weight, feed conversion ratio and egg quality}

The egg weight, feed conversion ratio to egg mass and various egg quality traits of Bangladeshi indigenous chicken genotypes in different ages are presented in Table 5. In scavenging system, several findings by Barua and Howlider (1990), Amin and Bhuiyan (1995), Ershad (2005) and Islam and Dutta (2010) reported average egg weight was around 35-40 g in native ND hen, although Ahmed et al. (2012) identified $42.07 \mathrm{~g}$ in ND and $44.17 \mathrm{~g}$ in NN chicken genotypes. In intensive system, Faruque et al. (2010) and (2013) recorded egg weight in ND, NN and $\mathrm{H}$ genotypes but they found lower egg weight in the age of sexual maturity for those chickens. These findings are also supported by Yeasmin et al. (2003) for the weight of first laying egg (29.76 g) and 46 week's egg (37.76 g) in ND genotype. Khan (1983)

Table 4: Egg fertility, hatchability and production percentage of local chicken genotypes in Bangladesh.

\begin{tabular}{|c|c|c|c|c|c|c|}
\hline \multirow[b]{2}{*}{ Trait } & \multicolumn{5}{|c|}{ Genotype } & \multirow[b]{2}{*}{ Reference } \\
\hline & $\begin{array}{c}\text { Deshi } \\
\text { (ND/FF) }\end{array}$ & $\begin{array}{l}\text { Naked Neck } \\
\text { (NN) }\end{array}$ & $\begin{array}{r}\text { Hilly } \\
(\mathrm{H})\end{array}$ & Assel & Yasine & \\
\hline \multirow[t]{7}{*}{ Fertility (\%) } & 83 & & & & & Hoque et al. (1975) \\
\hline & $91-96$ & & & & & Dutta et al. (2013) \\
\hline & & 71.50 & 52 & 53 & 57.80 & Huque and Salahuddin (2001) \\
\hline & 92.7 & 87.60 & & & & Islam et al. (2001) \\
\hline & 94.86 & 88.09 & 88.40 & & & Khatun et al. (2005) \\
\hline & $85.70-$ & $84.95-$ & $85.20-$ & & & Faruque et al. (2013) and (2015) \\
\hline & 94.39 & 95.00 & 97.57 & & & \\
\hline \multirow[t]{5}{*}{ Hatchability (\%) } & 75 & 43.10 & 46.10 & 26 & 60.70 & Barua (1992), Huque and Salahuddin (2001) \\
\hline & $84-88$ & & & & & Sarkar and Golam (2009), Dutta et al. (2013 \\
\hline & 86.38- & $57.66-$ & $77.82-$ & & & Faruque et al. (2010), (2013) and (2015) \\
\hline & 89.00 & 77.50 & 85.60 & & & \\
\hline & 88.74 & 93.50 & & & & Shahjahan et al. (2011) \\
\hline HDEP (\%) & 51.40 & 48.10 & 44.00 & & & Faruque et al. (2015) \\
\hline HHEP (\%) & 49.70 & 42.80 & 41.70 & & & Faruque et al. (2015) \\
\hline
\end{tabular}


The Status of Laying Traits in Indigenous Chicken of Bangladesh: A Review

and Yeasmin and Howlider (1998) observed feed conversion ratio 8.8 in local deshi(ND) chicken for egg mass production. Yeasmin and Howlider (1998) and Islam and Nishibori (2009) reported different egg quality traits of NN genotypes where dry matter of albumen (12.70-14.90\%) was the common trait among the studied different traits on egg quality. Yeasmin and Howlider (1998) found comparatively lower values than $\mathrm{NN}$ in average egg weight (33.50 g), yolk index (0.390), yolk dry matter $(51.03 \%)$, albumen index $(0.080)$, dry matter of albumen (13.43\%) and Haugh Unit (81.26) per egg in autosomal indigenous dwarf (adw) chicken genotype of Bangladesh.

In Kenyan native chicken, average egg weight of dwarf (38.1), normal (42.5) and NN (45.8 g) genotypes (Njenga, 2005) showed similar data to our country's findings which were partially agreed with the studies of Sunder et al. (2005) on Nicobari native hen (46.70-48.20 g) and improved native chicken breeds Vanaraja (51 g), Gramapriya (49 g) and Aseel chicken (41 g) of India (Sree et al., 2017). In case of improved backyard chicken in West Bengal of India, the average weights of first laid egg were $49.80 \mathrm{~g}, 51.20 \mathrm{~g}$ and $41.40 \mathrm{~g}$ in Gramapriya, Vanaraja and Haringhata breeds, respectively (Roy et al., 2018) while in another study of Egyptian native chicken at 46 and 94 weeks revealed that the egg weights were 44.26 and $28.60 \mathrm{~g}$ respectively (Hamouda et al., 2018). The FCR for egg mass was recorded 10.50-16.20 in Ethiopian local chicken at 22-44 weeks of age (Mogesse, 2007). This study also pointed out egg weight (34.11-41.75 g), yolk colour (3-4), yolk weight (10.81-13.34 g) and Haugh Unit (55-65) which were lower than Bangladeshi research findings (Islam and Nishibori, 2009; Ahmed et al. 2012; Faruque et al., 2010 and 2013) and similar to the parameters of egg weight $(40.73 \mathrm{~g})$ and yolk weight $(13.03 \mathrm{~g})$ in indigenous Fulani chicken of Nigeria (Fayeye et al., 2005).

\section{Conceptual breeding strategies for improving laying traits in village chicken}

Genetic improvement of indigenous chicken is difficult in the rural (in-situ) areas because of uncontrolled mating, poor management and irregular vaccination or deworming. However, several attempts for upgrading or crossbreeding

Table 5: Egg weight, FCR and egg quality in indigenous chicken genotypes of Bangladesh.

\begin{tabular}{|c|c|c|c|c|}
\hline \multirow[b]{2}{*}{ Trait } & \multicolumn{3}{|c|}{ Genotype } & \multirow[b]{2}{*}{ Reference } \\
\hline & $\begin{array}{c}\text { Deshi } \\
\text { (ND/FF) }\end{array}$ & $\begin{array}{l}\text { Naked Neck } \\
\text { (NN) }\end{array}$ & $\begin{array}{l}\text { Hilly } \\
(\mathrm{H})\end{array}$ & \\
\hline \multicolumn{5}{|l|}{ Egg weight (g) } \\
\hline \multirow[t]{5}{*}{ Average } & $35-39$ & 39.99 & $38-56$ & $\begin{array}{l}\text { Amin and Bhuiyan (1995), Ershad (2005), } \\
\text { Barua and Howlider (1990), Yeasmin } \\
\text { and Howlider (1998) }\end{array}$ \\
\hline & & $37.90-40.50$ & & Islam and Nishibori (2009) \\
\hline & 40.04 & & & Islam and Dutta (2010) \\
\hline & 42.07 & 44.17 & & Ahmed et al. (2012) \\
\hline & $42.94-43.50$ & $44.15-45.49$ & $40.32-43.24$ & Faruque et al. (2010) and (2013) \\
\hline At sexual maturity & & $25.8-26$ & 26.7-27.11 & Faruque et al. 2013 \\
\hline Laying of $1^{\text {st }}$ egg & 29.76 & & & Yeasmin et al. (2003) \\
\hline Laying on 46 weeks & 37.76 & & & \\
\hline \multirow[t]{2}{*}{ FCR (feed: egg mass) } & $8.60-8.80$ & & & Yeasmin and Howlider (1998) \\
\hline & 8.80 & & & Khan (1983) \\
\hline Egg mass (g/d/bird) & 16.74 & & & Yeasmin et al. (2003) \\
\hline Egg mass volume $\left(\mathrm{cm}^{3}\right)$ & 34.99 & & & Islam and Dutta (2010) \\
\hline \multicolumn{5}{|l|}{ Egg quality } \\
\hline Albumin height (mm) & & $4.10-5.30$ & & Islam and Nishibori (2009) \\
\hline Albumin width $(\mathrm{cm})$ & & $6.30-7.10$ & & \\
\hline Albumin weight $(\mathrm{g})$ & & $18.40-20.70$ & & \\
\hline Dry matter of albumin (\%) & & $12.70-14.90$ & & \\
\hline Yolk height $(\mathrm{mm})$ & & $16.20-17.40$ & & \\
\hline Yolk width $(\mathrm{cm})$ & & $3.70-3.80$ & & \\
\hline Yolk colour & & $3.10-4.60$ & & \\
\hline Yolk weight (g) & & $12.30-14.40$ & & \\
\hline Yolk index (\%) & & 0.39 & & Yeasmin and Howlider (1998) \\
\hline Yolk dry matter (\%) & & 52.27 & & \\
\hline Albumen index (\%) & & 0.08 & & \\
\hline Dry matter of albumen (\%) & & 14.24 & & \\
\hline Haugh unit (\%) & & 82.23 & & \\
\hline
\end{tabular}


was conducted in the early of 1970s for the development of indigenous chicken in Bangladesh using White Leghorn, New Hampshire and White Cornish birds with indigenous chicken (Hoque et al., 1975). In another backward poultry development programme during 1970s carried out by Bangladesh Agricultural University (BAU) and UNICEF, farmers were suggested to dispose their native cocks from flock and exotic breeding cocks of Rhode Island Red (RIR) or White Leghorn (WLH) $\times$ RIR or Australorp cocks of 1820 weeks were distributed in 100 rural villages with the aim to produce $50 \%$ Local-50\% Exotic crossbred chicken (Ahmed and Islam, 1985). After that the government's initiative for the improvement of native chicken was undertaken through improved exotic cockerel (WLH, RIR,
Fayoumi) exchange programme in the country which was continued up to 1990s (Bhuiyan et al., 2005). The collaboration of Bangladesh Livestock Research Institute (BLRI) with several national and international organizations was introduced toimprove the deshi cocks in different districts of Bangladesh for the genetic improvement of native chicken. Unfortunately, all the aforementioned activities were not succeeded in respective goals perfectly or facing various difficulties so far. Considering all, strict breeding strategies (Fig 3) are required to control the desired breeding programme including upgraded management system towards the development of laying traits among the indigenous village chicken of Bangladesh (Fig 4). However, it would be quite impossible unless and until follow the following steps carefully:

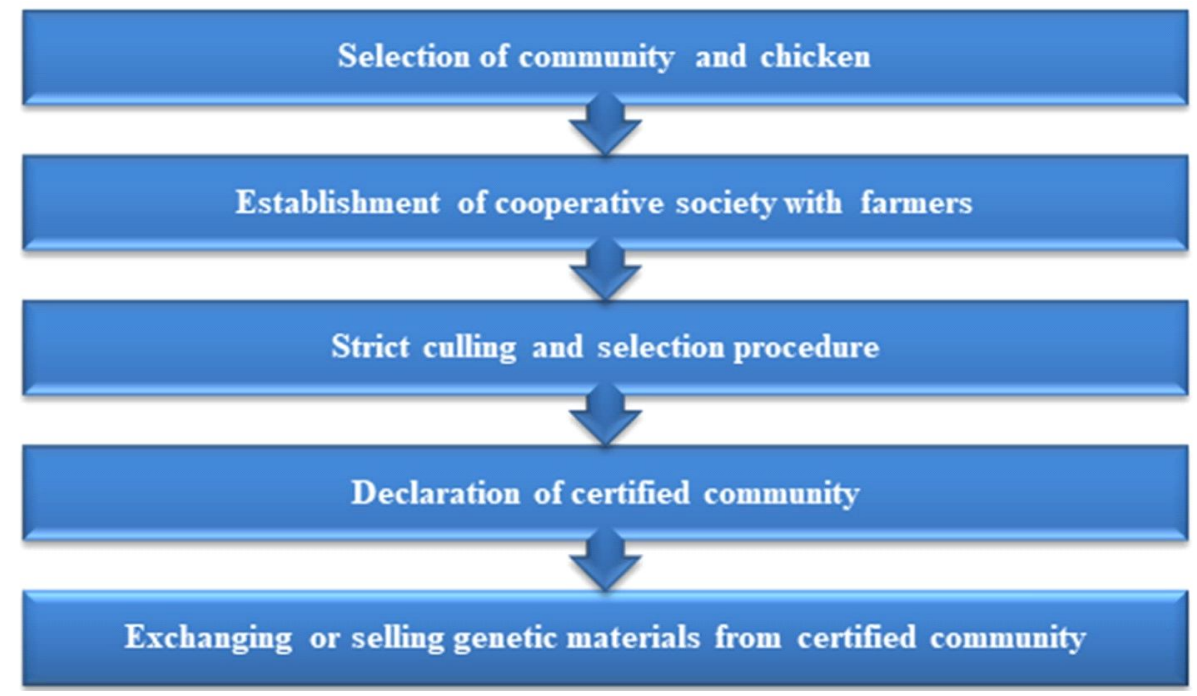

Fig 3: Flow chart of in-situ breeding strategies for village chicken.

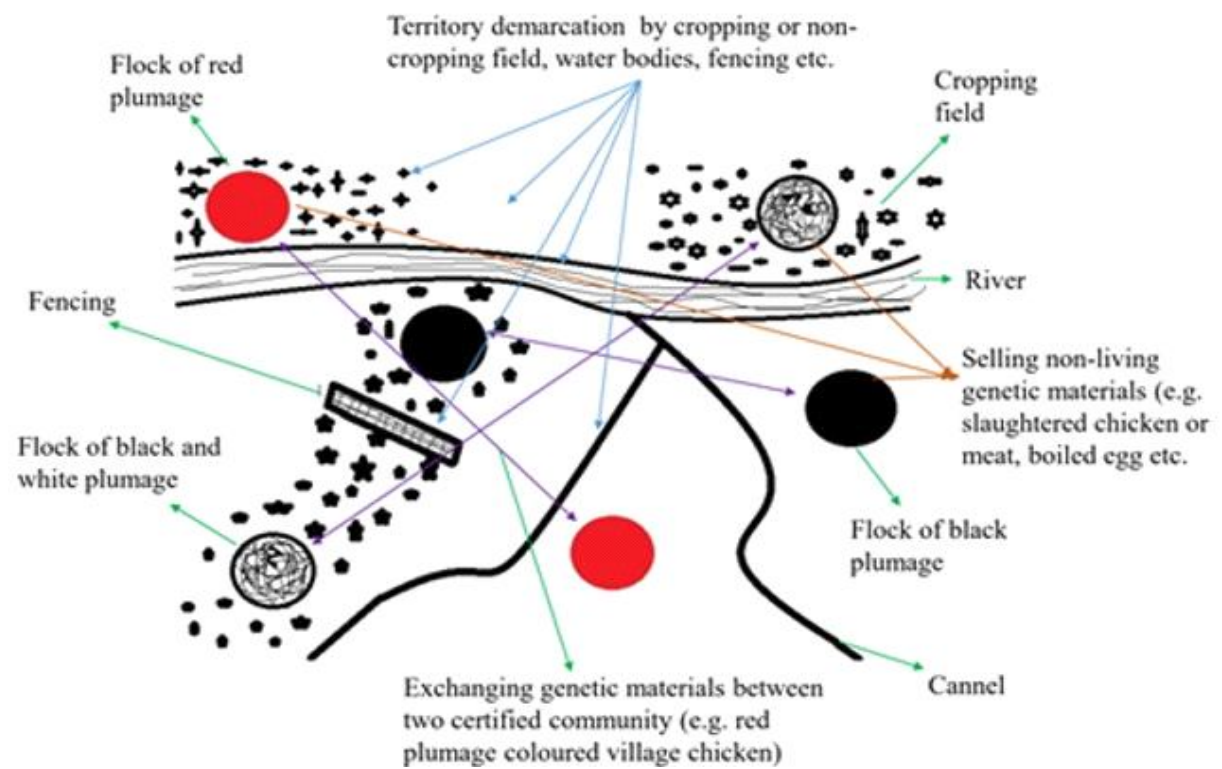

Fig 4: Demarcation and development of certified community having improved laying traits with specific plumage color and exchanging and selling genetic materials within certified community of village chicken. 


\section{Selection of community and chicken}

Community selection is important to control natural mating using a confined area which might be separated from other areas by any water body or crop field or desert or forest or fencing or any other barrier. All of the households in a selected community should be under the same umbrella either by direct chicken farming or supporting the farmers for executing farming by following rules and regulation of that community. In brief, if any farmer doesn't agree for such chicken farming, he/she will also not be able to purchase or exchange any chicken from anywhere to rear during this project period. In each communal territory, only one genotype with similar plumage coloured (e.g. non descriptive chicken predominant red plumage) chicken will be allowed to rear.

\section{Establishment of cooperative society with farmers}

A group of selected farmers from a community should form a cooperative society in which money will be deposited from each farmer for 10 laying hens and 2 breeding cocks $\left(G_{0}\right.$ population) with specific plumage color (e.g. red predominant), one year's vaccination and deworming cost and miscellaneous cost. This society will establish a quarantine shed centrally by which all the purchased chicken will be handed over to the farmers of this cooperative society after observing a quarantine period with required vaccination, medication and deworming. One of the farmers will have to take this responsibility and also for routine vaccination and deworming to the whole territory at a time according to prescribe schedule. The society will pay for this work to that volunteer.

\section{Strict culling and selection procedure}

The society will select another volunteer who will visit each farmer's farm regularly to collect mismatch plumage coloured (e.g. other than red plumage) cockerel and pullet as culling chicken ( $G_{1}$ population) from community. All such chicken will be slaughtered and sold in market or in any suitable place from where $80 \%$ cash will be transferred back to farmer and $20 \%$ will be deposited to the cooperative society for serving various development works for this project. From each hatching batch, 10\% cockerel and 50\% pullet will be raised to attain sexual maturity and production based on selection of plumage colour (e.g. red predominant) in $G_{1}$ population. Inside the community, breedable chicken and their egg exchange are possible but not allowed to outside. Such selection and culling will continue to $G_{2}, G_{3}$, $G_{4}$ and $G_{5}$ population while laying traits will be considered beside a selected plumage colour. In addition, $50 \%$ of the breeding cocks of each farmhouse will be exchanged to other farmers of this community rotationally through cooperative quarantine procedure to minimize inbreeding.

\section{Declaration of certified community}

After five generations, the desire plumage colour and laying traits would be fixed in chicken flock of a community by about 3.5 to 4 years and such a community would be considered as a certificate community for a specific plumage based developed village chicken variety.

\section{Exchanging or selling genetic materials from certified community}

A certified community having a specific plumage coloured chicken flock could only be exchanged genetic materials to a similar community in a division or a country through respective cooperative society. Without certified community, the selling genetic materials would be non-living either by slaughtering (meat) or boiling egg. A certified community will produce and use specific wing or leg band for exchanging or selling live chicken to another similar certified territory to control genetic admixture among the plumage coloured based developed flocks.

\section{CONCLUSION}

It is concluded that indigenous chicken of Bangladesh showed diverse laying performances in different regions or locations which could be the abundance of natural resources associated with better production and survivability. In addition, genetic merit was formed after a long-time random mating in specific regions. Planned short- and long-term community breeding programmes should be implemented to find out more productive and sustainable lines from native genetic resources. Necessary supports and funds are always needed from GOs, NGOs and international organizations to execute such plans and, disseminate and explore the outcomes throughout the country. But nevertheless, quantitative and genome wide selection procedure and functional study of candidate genes are recommended to confirm and accelerate the aforementioned ideas.

\section{REFERENCES}

Abegaz, A. and Gemechu, T. (2016). Indigenous chicken production system and their productive performance in Yeki Woreda, Southwestern Ethiopia. Agricultural and Biological Journal of Northern America. 7: 266-274.

Ahmed, M.F., Nishibori, M. and Islam, M.A. (2012). Production and price of indigenous naked neck and full feathered chicken reared under rural scavenging system in Bangladesh. Journal of Agricultural Extension and Rural Development. 4: $92-97$.

Ahmed, S. and Islam, M.N. (1985). Backyard poultry development in 100 villages sponsored by Bangladesh Agricultural University and UNICEF. Proceedings of the first National conference of Bangladesh Animal Husbandry Association. pp. 133-138.

Amin, M.R. and Bhuiyan, A.K.F.H. (1995). Production situation and the need of strategies for genetic improvement of backyard poultry in Bangladesh. Bangladesh Journal of Animal Science. 24: 35-49.

Barua, A. and Howlider, M.A.R. (1990). Prospect of native chickens in Bangladesh. Poultry Adviser. 23: 57-61.

Barua, A. (1992). A study on the performances of Rhode Island Red, indigenous chickens and their crossbred chickens with or without extra feeding under the rural condition of Bangladesh. M. Sc. Thesis, Department of Poultry Science, Bangladesh Agricultural University, Bangladesh. 
Barua, A., Devanath, S.C. and Hamid, M.A. (1992). A study on the performance of Rhode Island Red, White Leghorn and their cross with Naked neck chicken. Asian-Australasian Journal of Animal Sciences. 5: 25-27.

Benabdeljelil, K., Arfaoui, T. and Johnston, P. (2001). Traditional Poultry Farming in Morocco. In: Proceedings of the $10^{\text {th }}$ Conference of the Association of Institutions for Tropical Veterinary Medicine, held 20-23 August, Copenhagen.

Bhuiyan, A.K.F.H., Bhuiyan, M.S.A. and Deb, G.K. (2005). Indigenous chicken genetic resources in Bangladesh: Current status and future outlook. Animal Genetic Resources Information. 36: 73-84.

Bulbul, S.M. (1983). More Protein for the under Nourished through a Village Poultry Project. Maximum Livestock Production from Minimum Land. Proceedings of the $4^{\text {th }}$ seminar held in Bangladesh Agricultural University, Mymensingh 2202, Bangladesh.

Das, S.C., Chowdhury, S.D., Khatun, M.A., Nishibori, M., Isobe, N. and Yoshimura, Y. (2008). Poultry production profit and expected future projection in Bangladesh. World's Poultry Science Journal. 64: 99-118.

DLS (1998). Expansions and Activities. Department of Livestock Services. Dhaka. Bangladesh, pp. 131.

Dutta, R.K., Islam, M.S. and Kabir, M.A. (2013). Production performance of indigenous chicken (Gallus domisticus L.) in some selected areas of Rajshahi, Bangladesh. American Journal of Experimental Agriculture. 3: 308-323.

Ershad, S.M.E. (2005). Performance of hybrid layers and native hens under farmers' management in a selected area of Bangladesh. International Journal of Poultry Science. 4: 228-232.

Farooq, M., Javed, K., Durrani, F.R., Irfanullah, K. and Chand, N. (2003). Hatching performance of backyard hens in Peshawar, Pakistan. Livestock Research for Rural Development. 15(9): http://www.Irrd.org//rrd15/9/faro159. htm

Faruque, S., Islam, M.N. and Bhuiyan, A.K.F.H. (2015). Ex-situ improvement of indigenous chicken in Bangladesh. Tropical Agricultural Research. 26: 596-607.

Faruque, S., Islam, M.S., Afroz, M.A. and Rahman, M.M. (2013). Evaluation of the performance of native chicken and estimation of heritability for body weight. Journal of Bangladesh Academy of Sciences. 37: 93-101.

Faruque, S., Sarker, N.R., Islam, M.N. and Sarker, M.S.K. (2007). Performance of native chicken under intensive system. Journal of the Bangladesh Agricultural University. 5: 283-288.

Faruque, S., Siddiquee, N.U., Afroz, M.A. and Islam, M.S. (2010). Phenotypic characterization of native chicken under intensive management system. Journal of Bangladesh Agricultural University. 8: 79-82.

Fayeye, T.R., Adeshiyan, A.B. and Olugbami, A.A. (2005). Egg traits, hatchability and early performance of the Fulani-ecotype chicken. Livestock Research for Rural Development. 17: 8. http://www.Irrd.org/lrrd17/8/faye17094.htm.

Guèye, E.F. (1998). Village egg and fowl meat production in Africa. World's Poultry Science Journal. 54: 73-86.

Hamouda, R.E.S. and El-Menawey, M.A.R. (2018). Impact of Management Interventions Adoption on Chicken Productivity Under Family Poultry Production System in Egyptian Rural. Egyptian Poultry Science Journal. 38: 551-571.
Hoque, M., Ali, A. and Rahim, Q.M.F. (1975). A study on the Upgrading of Indigenous Chickens of Bangladesh with White Leghorn, New Hampshire and White Cornish. Poultry Breeding Project. Department of Animal Breeding and Genetics. Bangladesh Agricultural University, Mymensingh 2202, Bangladesh, pp. 28.

Horst, P. (1989). Native fowl as a reservoir for genomes and major genes with direct and indirect effects on productive adaptability and their potential for tropically oriented breeding plans. Archive für Geflügelkunde. 53: 93-101.

Hossary, M.A. and Galal, E.S.E. (1994). Improvement and adaptation of the fayoumi chicken. Animal Genetic Resources Information. 14: 33-41.

Huque, Q.M.E. and Haque, M.E. (1990). The onset of lay in indigenous hens following hatching of chicks. Poultry Adviser. 13: 57-60.

Huque, Q.M.E. and Salahuddin, M. (2001). Identification and Evaluation of Native Chicken. Progress Report, Poultry Production Research Division. BLRI, Savar, Dhaka, Bangladesh.

Huque, Q.M.E. (2001). Poultry Research in Bangladesh: Present Status and Its Implication for Future Research. In: Proceedings of the $2^{\text {nd }}$ International Poultry Show and Seminar. The World's Poultry Science Association-Bangladesh Branch, pp. 15-24.

Islam, M.A. and Nishibori, M. (2009). Indigenous naked neck chicken: A valuable genetic resource for Bangladesh. World's Poultry Science Journal. 65: 125-138.

Islam, M.A., Bulbul, S.M., Seeland, G. and Islam, A.B.M.M. (2001). Egg quality of different chicken genotypes in summer and winter. Pakistan Journal of Biological Sciences. 4: 1411-1414.

Islam, M.S., Bhuiyan, A.K.F.H., Bhuiyan, M.S.A. and Islam, S.S. (2007). Variability in performance of indigenous chicken. Journal of the Bangladesh Agricultural University. 5: 111-116.

Islam, M.S. and Dutta, R.K. (2010). Egg quality traits of indigenous, exotic and crossbred chickens (Gallus domesticus L.) in Rajshahi, Bangladesh. Journal of Life and Earth Science. 5: 63-67.

IUCN (2011). International Union for Conservation of Nature. Protocol for Monitoring of Impacts of Climate Change and Climate Variability in Bangladesh. Dhaka, Bangladesh, pp xiv +182 , http://cmsdata.iucn.org/downloads/for_web_ monitoring machanism_cc.pdf.

Jahan, S. (2013). A study on in-situ productive and reproductive performance of indigenous chicken at Jhinaigati upazilla of Bangladesh. M.Sc. Thesis, Department of Animal Breeding and Genetics, Bangladesh Agricultural University, Bangladesh.

Jahan, S., Islam, F., Bhuiyan, M.S.A. and Bhuiyan, A.K.F.H. (2017). Productive and reproductive performances of indigenous chicken in the rural condition of Bangladesh. Bangladesh Journal of Animal Science. 46: 121-127.

Khan, A.G. (1983). Improvement of desi bird (part-2). Poultry Adviser. 16: 67-78.

Khanh, V.V.T. (2004). Phenotypic characterization of ex-situ live animal conservation of some indigenous chicken breeds in Vietnam. Ph.D. Thesis, Agricultural University of Norway, Ås, Norway. 
The Status of Laying Traits in Indigenous Chicken of Bangladesh: A Review

Khatun, R., Islam, M.S., Faruque, S., Azmal, S.A. and Uddin, M.S. (2005). Study on the productive and reproductive performance of 3 native genotypes of chicken under intensive management. Journal of Bangladesh Agricultural University. 3: 99-104.

Mogesse, H.H. (2007). Phenotypic and genetic characterization of indigenous chicken populations in northwest Ethiopia. Ph.D. Thesis. Department of Animal, Wildlife and Grassland Sciences, University of the Free State, South Africa.

Mwalusanya, N.A., Katule, A.M., Mutayoba, S.K., Mtambo, M.M.A., Olsen, J.E. and Minga, U.M. (2001). Productivity of local chickens under village management conditions. Tropical Animal Health and Production. 34: 405-416.

Njenga, S.K. (2005). Productivity and socio-cultural aspects of local poultry phenotypes in coastal Kenya. Ph. D. Thesis, The Royal Veterinary and Agricultural University, Copenhagen.

Okada, I., Maeda, Y., Ota, K., Namikawa, T., Amano, T., Kurosawa, Y., Hasnath, M.A, Farooque, M.O., Majid, M.A. and Karim, M.D.R. (1987). Genetical Studies on Breed Difference of the Native Chickens in Bangladesh. In: Genetic studies on Breed Difference of the Native Domestic Animals in Bangladesh, Part 2. Hiroshima University, pp. 11-26.

Parveen, A., Khan, S.H., Rashid, A. and Aurangzeb, M. (2013). Impact of training on rural chicken production reared by women in Islamabad/Rawalpindi, Pakistan. Annual Review and Research in Biology. 3: 714-723.

Paul, D.C. and Huque, Q.M.E. (1996). Performance and Phenotypic Characteristics of Indigenous Germplasm of Chicken in Bangladesh. Proceedings of the XX World's Poultry Congress, New Delhi, India, 2-5 September. 4: 20.

Petrus, N.P. (2011). Characterisation and production performance of indigenous chickens in northern Namibia regions. Ph.D. Thesis, The University of Namibia, Namibia.

Roy, A., Roy, P.S., Mandal, N., Kumar, S. and Biswas, P.K. (2018). comparative performances of improved poultry breeds under intensive condition in Murshidabad district of West Bengal, International Journal of Current Microbiology and Applied Sciences. 7: 1504-1508.

Sarkar, K. and Bell, J.G. (2006). Potentialities of deshi chickens and its role in poverty alleviation and nutrition security for rural household. International Network for Family Poultry Development (INFPD) Newsletter. 16: 15-26.

Sarkar, K. and Golam, M. (2009). A move from subsistence to semicommercial family poultry farming with local chickens: effective strategies for family poultry in Bangladesh. World's Poultry Science Journal. 65: 251-259.

Sazzad, H.M. (1993). Comparative study on egg production and feed efficiency of different breeds of poultry under intensive and rural conditions in Bangladesh. Livestock Research for Rural Development. 3: 65-69.

Sazzad, M.H. (1986). Reproductive Performance of Deshi Hens under Scavenging and Intensive System of Rearing. Proceedings of $1^{\text {st }}$ Annual Livestock Research Workshop. Bangladesh Livestock Research Institute, Savar, Dhaka, pp. 60-62.
Sazzad, M.H., Ebadul, M.H. and Asaduzzaman, M.U. (1990). Egg production by desi (indigenous) hens in rural Bangladesh. Animal Breeding Abstracts. 58: 3929.

Shahjahan, M. and Bhuiyan, A.K.F.H. (2016). Socio-economic condition and indigenous poultry production scenario in a selected cluster area of Bangladesh. Asian-Australasian Journal of Bioscience and Biotechnology. 1: 557-563.

Shahjahan, M., Amin, M.R. and Bhuiyan, A.K.F.H. (2011). Diversity in Performance of Indigenous Chicken in Some Selected Areas of Bangladesh in-situ. Proceedings of $9^{\text {th }}$ Asia Pacific Poultry Conference, the World's Poultry Science Association Taiwan Branch. 20-23 March, Taipei, Taiwan. Mon-S408.CD.

Sharma, R.K. (2004). Utilization of Heterosis Between Indigenous and Exotic Chicken under Suboptimal Condition in India. In: Proceedings of the $22^{\text {nd }}$ World's Poultry Congress, held 8-13 June, Istanbul, Turkey.

Sørensen, P. (2010). Chicken genetic resources used in smallholder production systems and opportunities for their development. Food and Agriculture Organization of the United Nations, FAO, Rome, http://www.fao.org/docrep/013/al675e/ al675e00.pdf.

Sree, E.K., Nirmala, T.V. and Reddy, R.V.S.K. (2017). Comparative Performance of Different Varieties of Chicken Under Backyard System of Rearing in Tribal and Rural Areas of West Godavari District, A.P. International Journal of Science, Environment and Technology. 6: 1100 - 1104.

Sunder, J., Chatterjee, R.N., Rai, R.B., Kundu, A., Senani, S., Singh A.K. and Jeyakumar, S. (2005). Production performance of indigenous and crossbred poultry germplasm of Andaman and Nicobar Island. Indian Journal of Animal Science. 75: 1326-1328.

Tadelle, D., Million, T. Alemu, Y. and Peters, K.J. (2003). Village chicken production systems in Ethiopia: 1. Flock characteristics and performance. Livestock Research for Rural Development, 15, 1, http://www.Irrd.org//rrd15/1/ tadea151.htm.

Yeasmin, T. and Howlider, M.A.R. (1998). Comparative physical feature, egg production and egg quality characteristics of normal and dwarf indigenous (desi) hens of Bangladesh. Journal of Applied Animal Research. 13: 191-196.

Yeasmin, T., Howlider, M.A.R., Ahammad, M.U. and Dinajpur, B. (2003). Effect of introgressing dwarf gene from Bangladeshi indigenous to exotic breeds on egg production. International Journal of Poultry Science. 2: 264-266.

Yoshimura, Y., Barua, A., Heryanto, B., Ohira, H. and Zheng, W. (1997). Reproductive physiology in domestic animals: as a basic knowledge to improve poultry production in Asian countries. Journal of International Development and Cooperation. 3: 27-41. 